\title{
Tentang Ekor yang Tak Lagi Beracun: Kritik Konseptual atas Sanksi Administratif dalam Hukum Lingkungan di Indonesia \\ Andri Gunawan Wibisana ${ }^{1}$
}

\begin{abstract}
Abstrak
Sanksi administratif merupakan sanksi yang sangat penting, dan dalam banyak kasus merupakan sanksi yang harus pertama kali diterapkan, dalam penegakan hukum lingkungan. UUPPLH memiliki beberapa ketentuan mengenai jenis dan urutan penjatuhan sanksi administratif. Ketentuan ini kemudian ditindaklanjuti dengan Peraturan Menteri LH Nomor 2 Tahun 2013 tentang Pedoman Penerapan Sanksi Administratif di Bidang Perlindungan dan Pengelolaan Lingkungan Hidup. Artikel ini bermaksud membahas jenis sanksi administratif dalam hukum lingkungan Indonesia, serta mengevaluasi dan mengidentifikasi beberapa kekeliruan dalam memahami sanksi administratif, yang pada akhirnya dapat dan telah berkontribusi pada tidak efektifnya penegakan hukum lingkungan di Indonesia. Artikel ini menemukan dua kekeliruan dalam konsep sanksi administratif di Indonesia. Pertama, UUPPLH dan Peraturan Menteri LH bermasalah dalam memahami paksaan pemerintah. Kedua, UUPPLH dan Peraturan Menteri LH mencampuradukkan dan menyamakan antara uang paksa dengan denda administratif. Kedua persoalan dalam penafsiran sanksi administratif ini berkontribusi pada melemahnya sanksi administratif sebagai sanksi yang seharusnya paling utama dalam penegakan hukum lingkungan.
\end{abstract}

Kata Kunci: sanksi administratif, paksaan pemerintah, uang paksa, denda administratif

\section{Abstract}

Administrative sanctions play a vital role, and in many cases are the primary sanctions, in the enforcement of environmental law. The 2009 Environmental Law has several provisions regarding the type of administrative sanctions and procedures for applying them. The provisions are detailed in the Regulation of Minister of Environment Number 2 of 2013 concerning Guidelines for the Application of Administrative Sanctions in the Field of Environmental Protection and Management. This paper discusses the types of administrative sanctions in Indonesian environmental law. It further evaluates and identifies flaws in understanding administrative sanctions. This paper finds two misconceptions about the concept of administrative sanctions in Indonesia. First, the 2009 Law and the Ministerial Regulation incorrectly interpret government coercive action as merely an order for those who violate the law, without any possibility

\footnotetext{
${ }^{1}$ Penulis adalah dosen hukum lingkungan pada Falkultas Hukum Universitas Indonesia. Memperoleh Sarjana Hukum dari Fakutas Hukum Universitas Indonesia (1998), LLM dari Utrecht University (2002), dan Doktor dari Maastricht University (2008).
} 
for the government agency to carry out the order by itself if the violators fail to perform the order. Second, the 2009 Law and the Ministerial Regulation mistakenly translate a penalty payment (dwangsom) as an administrative fine. The misconceptions, in turn, could potentially lead to the decreased effectiveness of administrative sanctions as an essential tool for the enforcement of environmental law in Indonesia.

Keywords: administrative sanction, coercive action, penalty payment, administrative fine

\section{Pendahuluan}

Sanksi administratif merupakan bagian penting dalam penegakan hukum, termasuk penegakan hukum lingkungan. Pada bagian akhir sebuah peraturan, biasanya dijelaskan beberapa jenis sanksi administratif bagi pelanggaran atas peraturan tersebut. Karena letaknya yang berada pada bagian akhir, para sarjana menyebut sanksi administratif sebagai in cauda venenum, racun yang berada di ekor. $^{2}$

Pada dasarnya sanksi administratif merupakan bagian dari penegakan hukum. Hal ini dapat dilihat dari pandangan van Wijk, et al. yang menyatakan " $[a]$ ls het moet, kan de naleving van uit bestuursrechtelijke normen voortvloeiende verplichtingen worden afgedwongen met sancties, dat wil zeggen door het publiekrecht voorzi- ene, belastende maatregelen die de overheid jegens een burger kan aanwenden als reactie op niet-naleving van verplichtingen die voortvloeien uit bestuursrechtelijke normen". ${ }^{3}$ Van Wijk, et al. menempatkan sanksi administratif sebagai bagian dari penegakan hukum dalam rangka menuntut penaatan terhadap kewajiban berdasarkan peraturan perundang-undangan. Oleh para pengarang ini, sanksi administratif dianggap sebagai sarana hukum publik berupa penjatuhan beban oleh pemerintah terhadap rakyatnya sebagai respons atas ketidaktaatan terhadap kewajiban yang muncul dari peraturan perundangundangan.

Data dari Kementerian Lingkungan Hidup dan Kehutanan (KLHK) pada tahun 2015-20174 menunjukkan hal berikut.

\footnotetext{
${ }^{2}$ Ridwan H.R., Hukum Administrasi Negara, Cet. 3 (Jakarta: RajaGrafindo Persada, 2006), hal. 313.

${ }^{3}$ H.D. van Wijk, Willem Konijnenbelt, dan Ron van Male, Hoofdstukken van Bestuursrecht (Den Haag: Elsevier Juridisch, 2008), hal. 452.

${ }^{4}$ Ditjen GAKKUM KLHK, “Tiga Tahun Direktorat Jenderal Penegakan Hukum Lingkungan Hidup dan Kehutanan 2015 - 2017", https://docplayer.info/71504638-Tiga-tahun-direktorat-jenderalpenegakan-hukum-lingkungan-hidup-dan-kehutanan.html, hlm. 16.
} 
Tentang Ekor yang Tak Lagi Beracun: Kritik Konseptual atas Sanksi Administratif dalam Hukum Lingkungan di Indonesia

\begin{tabular}{|l|r|}
\hline \multicolumn{1}{|c|}{ Jenis Sanksi } & \multicolumn{2}{c|}{$\begin{array}{c}\text { Jumlah } \\
\text { Kasus }\end{array}$} \\
\hline Surat Peringatan & 115 \\
\hline Teguran Tertulis & 23 \\
\hline Paksaan Pemerintah & 206 \\
\hline Pembekuan Izin & 21 \\
\hline Pencabutan Izin & 4 \\
\hline TOTAL & $\mathbf{3 6 9}$ \\
\hline
\end{tabular}

Sementara itu, data lain KLHK ${ }^{5}$ menunjukkan bahwa dari total 102 sanksi administratif yang dijatuhkan pada tahun 2016 (15 teguran tertulis dan 87 paksaan pemerintah), 75 kegiatan/usaha memberikan respons taat, sedangkan 27 tidak taat. Tidak dijelaskan tindakan selanjutnya untuk perusahaan yang menunjukkan ketidaktaatan terhadap sanksi yang dijatuhkan.

Apakah kondisi penjatuhan sanksi administratif di atas ideal, dalam arti dapat secara optimal menciptakan efek jera (deterrent effect)? Salah satu cara untuk memperlihatkan apakah data ini menunjukkan kondisi yang ideal adalah dengan melihat konsep paksaan pemerintah dan denda di Indonesia. Artikel ini dimaksudkan untuk memperlihatkan persoalan konseptual dalam sanksi administratif di Indonesia, dengan fokus pada jenis sanksi paksaan pemerintah dan denda.

Artikel ini akan memperlihatkan bahwa UUPPLH ${ }^{6}$ dan Peraturan Menteri yang melaksanakannya, yaitu PermenLH Nomor 2 Tahun 2013 tentang Pedoman Penerapan Sanksi Administratif di Bidang Perlindungan dan Pengelolaan Lingkungan Hidup, ${ }^{7}$ memiliki persoalan dalam memahami konsep sanksi administratif. Pertama, UUPPLH dan PermenLH keliru dalam memahami paksaan pemerintah. Dalam hal ini, paksaan pemerintah diartikan semata-mata sebagai sebuah tindakan hukum (rechtelijk handelen), tanpa disertai dengan adanya tindakan nyata (feitelijk handelen). Kedua, UUPPLH dan PermenLH juga gagal memahami perbedaan antara uang paksa dan denda. Hal ini terlihat dari dicampuradukkannya kedua jenis sanksi tersebut. Kedua kekeliruan tersebut merupakan kekeliruan fatal yang dapat mengarah pada tidak efektifnya sarana penegakan hukum administratif. Secara konseptual terlihat bahwa ekor itu ternyata tidak lagi beracun.

Artikel ini akan dimulai dengan penjelasan mengenai sanksi administratif sebagaimana diatur di dalam UUPPLH

${ }^{5}$ Ditjen GAKKUM KLHK, “Capaian Penegakan Hukum Lingkungan Hidup dan Kehutanan 2016”, tersedia pada: https://docplayer.info/71110632-Capaian-penegakan-hukum-lingkungan-hidup-dan -kehutanan-januari-direktorat-jenderal-penegakan-hukum.html, hlm. 4.

${ }^{6}$ Indonesia, Undang-Undang Perlindungan dan Pengelolaan Lingkungan Hidup, UU No. 32 Tahun 2009, LN Tahun 2009 No. 140, TLN No. 5059.

${ }^{7}$ Indonesia, Menteri Lingkungan Hidup dan Kehutanan, Peraturan Menteri LH (PerMenLH) Nomor 2 tahun 2013 tentang Pedoman Penerapan Sanksi Administratif di Bidang Perlindungan dan Pengelolaan Lingkungan Hidup, BN Tahun 2013 Nomor 314. 
dan PermenLH Nomor 2 Tahun 2013. Bagian selanjutnya menjelaskan pandangan teoretis tentang sanksi administratif. Artikel ini menggunakan berbagai literatur untuk menjelaskan definisi, unsur, dan jenis dari sanksi administratif. Literatur yang digunakan lebih banyak merujuk pada literatur sanksi administratif di Belanda dikarenakan sebagian besar pembahasan mengenai Hukum Administrasi Negara dan sanksi administratif di Indonesia masih sangat dipengaruhi oleh literatur di Belanda. Artikel akan mengetengahkan bagaimana perkembangan literatur HAN di Belanda dalam hubungannya dengan sanksi administratif, termasuk sanksi administratif dalam konteks hukum lingkungan. Bagian selanjutnya memberikan analisis kritis atas perumusan sanksi administratif dari hukum lingkungan yang ada. Bagian ini akan memperlihatkan proyeksi mengapa kekeliruan konseptual terhadap sanksi administratif akan mengurangi efek jera dari sanksi administratif. Bagian terakhir merupakan ulasan penutup.

\section{Sanksi Administratif Menurut UUPPLH}

UUPPLH menjelaskan bahwa sanksi administratif dijatuhkan apabila berdasarkan pengawasan ditemukan bahwa penanggung jawab usaha dan/atau kegi- atan tidak taat terhadap peraturan perundang-undangan di bidang perlindungan dan pengelolaan lingkungan hidup dan/ atau ketentuan dalam Izin lingkungan. Jika dalam pengawasan ditemukan pelanggaran terhadap izin lingkungan atau izin perlindungan dan pengelolaan lingkungan hidup (PPLH), maka Menteri, Gubernur, atau Bupati/Walikota dapat menjatuhkan sanksi administratif. ${ }^{8}$ Sanksi tersebut terdiri dari teguran tertulis, paksaan pemerintah, pembekuan dan pencabutan izin lingkungan/izin perlindungan, ${ }^{9}$ dan denda. ${ }^{10}$

\section{A. Teguran Tertulis}

Teguran tertulis merupakan salah satu sanksi administratif yang disebutkan di dalam Pasal 76 ayat (2) UUPPLH. Pada dasarnya, semua sanksi administratif harus dimulai dengan adanya teguran. Pengecualian terhadap keharusan adanya teguran hanya dapat dilakukan untuk sanksi paksaan pemerintah, dan untuk alasan yang secara limitatif ditentukan oleh UUPPLH. ${ }^{11}$

Ketentuan UUPPLH ini selanjutnya diterangkan secara singkat oleh PermenLH Nomor 2 Tahun 2013, yang menyatakan bahwa teguran tertulis dijatuhkan kepada mereka yang melanggar persyaratan dan kewajiban yang tercantum dalam izin, baik izin lingkungan maupun

\footnotetext{
${ }^{8}$ Indonesia, Op. Cit.,Undang-Undang Perlindungan dan Pengelolaan Lingkungan Pasal 76 (1).

${ }^{9}$ Ibid, (2).

${ }^{10}$ Ibid, Pasal 81.

${ }^{11}$ Lihat pengecualian dan syaratnya pada pembahasan mengenai sanksi paksaan pemerintah.
} 
izin PPLH, tetapi belum menimbulkan dampak negatif terhadap lingkungan. ${ }^{12}$ Ketentuan ini dijelaskan lebih lanjut di dalam lampiran dari PermenLH tersebut.

Menurut lampiran tersebut, selain kepada pelanggar kewajiban di dalam izin, teguran tertulis juga dapat dijatuhkan kepada pelanggar aturan perundang-undangan, sepanjang pelanggaran itu masih dapat diperbaiki dan belum menimbulkan dampak. Karena itu, pelanggaran yang dijatuhi sanksi teguran tertulis adalah pelanggaran administratif maupun teknis. Pelanggaran administratif di sini, antara lain, meliputi a) tidak disampaikannya laporan; b) tidak dimilikinya log book dan neraca limbah B3; dan c). tidak dimilikinya label dan simbol limbah B3. ${ }^{13}$ Sedangkan pelanggaran teknis adalah pelanggaran yang perbaikannya ringan, karena dapat dilakukan dalam waktu singkat, tidak memerlukan teknologi yang tinggi, tidak memerlukan penanganan oleh ahli, dan berbiaya murah. Pelanggaran ini meliputi: a) parameter BOD5 kurang dari 0,2 ppm; b) belum adanya kelampauan kriteria baku kerusakan lingkungan hidup; c). tidak dilaporkannya kerusakan atau gangguan pada instalasi pengolahan air limbah kepada pejabat yang berwenang; d). ter- jadinya kerusakan atau gangguan pada mesin produksi; e) adanya penanganan teknis yang lebih baik untuk mencegah pencemaran dan/atau perusakan lingkungan; f) adanya pelanggaran yang dapat menimbulkan potensi terjadinya pencemaran dan/atau perusakan lingkungan hidup; g). belum dilaporkannya pelaksanaan RKL-RPL atau UKL-UPL; h) tidak dilakukannya pencatatan debit harian; i) tidak dilakukannya pelaporan swapantau; j) tidak terakreditasinya laboratorium pengujian yang digunakan; k) belum dilakukannya pencatatan dan pelaporan kegiatan penyimpanan limbah B3; l) belum dilakukannya pendataan jenis dan volume limbah B3; m) tidak dipasangnya lampu penerangan, simbol, label limbah B3; n) tidak dimilikinya SOP penyimpanan, pengumpulan, pemanfaatan, pengolahan dan penimbunan limbah B3, dan tidak adanya log book limbah B3; dan o) belum melakukan pencatatan dan pelaporan kegiatan pemanfaatan, pengumpulan limbah B3. ${ }^{14}$

\section{B. Paksaan Pemerintah}

Paksaan pemerintah adalah sanksi yang paling panjang lebar dibahas di dalam UUPPLH dan PermenLH Nomor 2 Tahun 2013. Paksaan pemerintah adalah "sanksi administratif berupa tindakan nyata", yang ditujukan "untuk meng-

\footnotetext{
${ }^{12}$ Indonesia, Op. Cit., Peraturan Menteri LH Nomor 2 tahun 2013, Pasal 4 (2).

${ }^{13} \mathrm{Ibid}$, Lampiran I, hlm. 3. ${ }^{14} \mathrm{Ibid}$, hlm. 3-4.

${ }^{14} \mathrm{Ibid}, \mathrm{hlm}, 4$
} 
hentikan pelanggaran dan/atau memulihkan dalam keadaan semula." ${ }^{15}$

Pada dasarnya, paksaan pemerintah harus didahului oleh teguran tertulis. Hanya dalam kondisi tertentu paksaan pemerintah dapat langsung dijatuhkan. Kondisi tertentu tersebut adalah: a). adanya ancaman yang sangat serius bagi manusia dan lingkungan hidup; b). adanya dampak yang lebih besar dan lebih luas jika pencemaran/kerusakan tidak segera dihentikan; dan/atau c). adanya kemungkinan kerugian lingkungan yang lebih besar akan timbul jika pencemaran dan/atau perusakan tidak segera dihentikan. ${ }^{16}$

UUPPLH tidak menjelaskan jenis pelanggaran yang dapat dijatuhi sanksi paksaan pemerintah. Menurut PermenLH, paksaan pemerintah dijatuhkan jika terjadi pelanggaran terhadap syarat dan kewajiban yang tercantum di dalam izin lingkungan atau izin PPLH, dan/atau terjadi pencemaran/kerusakan ling- kungan. ${ }^{17}$

UUPPLH menentukan bahwa sanksi paksaan pemerintah dapat berupa: a) menghentikan sementara kegiatan produksi; b) memindahkan sarana produksi; c) menutup saluran pembuangan air limbah atau emisi; d). melakukan pembongkaran; e) melakukan penghentian sementara seluruh kegiatan; dan f) melakukan tindakan lain sebagai penghentian pelanggaran dan pemulihan fungsi lingkungan. Selain memberikan perintah kepada pelanggar, tindakan lain yang dapat dilakukan oleh pemerintah di dalam paksaan pemerintah adalah melakukan penyitaan terhadap barang atau alat yang berpotensi menimbulkan pelanggaran. ${ }^{18}$

\section{Denda}

PermenLH memberikan definisi denda administratif sebagai berikut.

“...pembebanan kewajiban untuk melakukan pembayaran sejumlah uang tertentu kepada penanggung

\footnotetext{
${ }^{15}$ Indonesia, Op. Cit., Undang-Undang Perlindungan dan Pengelolaan Lingkungan, Pasal 80 (2).

${ }^{16}$ Indonesia, Op. Cit., Peraturan Menteri LH Nomor 2 tahun 2013, Pasal 4 (2).

${ }^{17}$ PerMenLH menjelaskan lebih lanjut contoh dari pelanggaran yang dapat dijatuhi paksaan pemerintah, yaitu: a) tidak dibuatnya Instalasi Pengolahan Air Limbah (IPAL); b) tidak dimilikinya Tempat Penyimpanan Sementara (TPS) untuk limbah B3; c) tidak dimilikinya alat pengukur laju alir air untuk limbah cair (flow meter); d) tidak dipasangnya tangga pengaman pada cerobong emisi; e) tidak dibuatnya lubang sampling pada cerobong emisi; f) terjadinya pembuangan/pelepasan limbah yang melebihi baku mutu air limbah; g) tidak dipenuhinya persyaratan di dalam izin; h) tidak optimalnya kinerja IPAL; i) tidak dipisahkannya saluran air limbah dengan limpasan untuk air hujan; j) tidak dibuatnya saluran air limbah yang kedap air; k) tidak optimalnya kinerja fasilitas pengendalian pencemaran udara; 1 ) tidak terpasangnya alat scrubber; $\mathrm{m}$ ) tidak dimilikinya fasilitas sampling udara; $\mathrm{n}$ ) dibuangnya limbah B3 di luar TPS untuk limbah B3; o) tidak dimilikinya saluran atau bak penampung tumpahan limbah B3. Lihat: PerMenLH Nomor 2 tahun 2013, Lampiran I, hal. 4-5.

${ }^{18}$ Indonesia, Op. Cit., Undang-Undang Perlindungan dan Pengelolaan Lingkungan, Pasal 80 (1).
} 
Tentang Ekor yang Tak Lagi Beracun: Kritik Konseptual atas Sanksi Administratif dalam Hukum Lingkungan di Indonesia

jawab usaha dan/atau kegiatan karena terlambat untuk melakukan paksaan pemerintahan.

"Pengenaan denda terhadap keterlambatan melaksanakan paksaan pemerintah ini terhitung mulai sejak jangka waktu pelaksanaan paksaan pemerintah tidak dilaksanakan." ${ }^{19}$

PermenLH menggunakan istilah denda administratif, yang di dalam bahasa Belanda disebut administratieve/bestuurlijke boete. Selain itu, kutipan di atas juga memperlihatkan bahwa denda administratif didefinisikan sebagai pembayaran atas keterlambatan pelaksanaan paksaan pemerintah. Definisi ini sejalan dengan ketentuan UUPPLH yang menyatakan:

“Setiap penanggung jawab usaha dan/atau kegiatan yang tidak melaksanakan paksaan pemerintah dapat dikenai denda atas setiap keterlambatan pelaksanaan sanksi paksaan pemerintah." ${ }^{20}$ Ketentuan ini dijelas- kan lebih lanjut di dalam PermenLH, yang juga menyatakan bahwa pemerintah dapat menetapkan denda untuk keterlambatan pelaksanaan paksaan pemerintah. ${ }^{21}$

Tepatkah makna "denda administratif" ini? Sebagai perbandingan di awal, dapat dilihat dengan denda administratif menurut PP Nomor 8 tahun 1999 tentang Pemanfaatan Jenis Tumbuhan dan Satwa Liar. ${ }^{22}$ PP tersebut menjelaskan beberapa pasal tentang denda administratif untuk perdagangan tumbuhan dan satwa liar (TSL), yaitu Pasal 50 ayat (3), Pasal 53, Pasal 54, Pasal 56, Pasal 58, Pasal 59, dan Pasal 63. Sebagai contoh, Pasal 50 ayat (3) menyatakan: "Perbuatan sebagaimana dimaksud dalam ayat (1) dengan serta-merta dapat dihukum denda administrasi sebanyak-banyaknya Rp.50.000.000,00 (lima puluh juta rupiah) dan atau dihukum tidak diperbolehkan melakukan kegiatan pengkajian, penelitian dan pengembangan terhadap tumbuhan liar dan satwa liar untuk wak-

\footnotetext{
${ }^{19}$ Indonesia, Op.Cit., Peraturan Menteri LH Nomor 2 tahun 2013, Lampiran I, hlm. 5.

${ }^{20}$ Indonesia, Op. Cit., Undang-Undang Perlindungan dan Pengelolaan Lingkungan, Pasal 81.

${ }^{21}$ Indonesia, Op. Cit., Peraturan Menteri LH Nomor 2 tahun 2013, Pasal 6.

${ }^{22}$ Indonesia, Pemerintah Indonesia, Peraturan Pemerintah tentang Pemanfaatan Jenis Tumbuhan dan Satwa Liar, PP Nomor 8 Tahun 1999 tentang LN tahun 1999 Nomor 15, TLN Nomor 3802.

${ }^{23}$ Pasal 50 ayat (1) merupakan pernyataan bahwa perbuatan tanpa izin untuk menggunakan TSL yang dilindungi untuk kepentingan pengkajian, penelitian, dan pengembangan, sebagaimana diatur dalam Pasal 4 ayat (2), akan dihukum sebagai perbuatan yang melanggar Pasal 21 UU Nomor 5 tahun 1990 tentang Konservasi Sumber Daya Alam Hayati dan Ekosistemnya. Selanjutnya, berdasarkan Pasal 40 UU Nomor 5 tahun 1990, kegiatan yang melanggar Pasal 21 diancam dengan pidana Pasal 4penjara paling lama lima tahun dan denda paling banyak Rp 100 juta (untuk pelanggaran dengan kesengajaan) dan pidana kurungan paling lama satu tahun dan denda paling banyak Rp 50 juta.

Berdasarkan ketentuan di atas, maka selain diancam dengan sanksi pidana, penggunaan TSL yang dilindungi tanpa izin untuk kegiatan pengkajian, penelitian, dan pengembangan dapat dijatuhkan pula sanksi administratif berupa denda administratif dan larangan melakukan pengkajian, penelitian, dan pengembangan.
} 
tu paling lama 5 tahun." 23

Istilah "serta-merta" di dalam sanksi tersebut menunjukkan bahwa denda administratif menurut PP Nomor 8 tahun 1999 diterapkan pada saat terjadinya pelanggaran, bukan sebagai reaksi atas kegagalan melakukan paksaan pemerintah. Hal ini berbeda dengan denda administratif menurut UUPPLH dan PermenLH Nomor 2 Tahun 2013, yang melihat denda administratif justru sebagai respons atas tidak dilakukannya paksaan pemerintah oleh pihak yang dikenakan sanksi (pelanggar).

\section{Pembekuan dan Pencabutan Izin}

Terkait pembekuan dan pencabutan izin, UUPPLH menyatakan:

"Pengenaan sanksi administratif berupa pembekuan atau pencabutan izin lingkungan sebagaimana dimaksud dalam Pasal 76 ayat (2) huruf c dan huruf d dilakukan apabila penanggung jawab usaha dan/atau kegiatan tidak melaksanakan paksaan pemerintah." 24

UUPPLH menafsirkan bahwa reaksi atas tidak dilakukannya paksaan pemerintah adalah sanksi pembekuan atau pencabutan izin. Pembekuan izin dapat dilakukan dengan atau tanpa batas waktu. ${ }^{25}$ Pembekuan izin diterapkan jika terjadi tiga kondisi berikut. Pertama, pelaku usaha/kegiatan tidak melaksanakan paksaan pemerintah. Kedua, pelaku usaha/kegiatan melakukan suatu kegiatan selain dari kegiatan yang tercantum di dalam izin. Ketiga, ditemukannya dugaan pemalsuan dokumen persyaratan izin. ${ }^{26}$ Adapun syarat lainnya adalah bahwa pemegang izin belum menyelesaikan secara teknis apa yang seharusnya menjadi kewajibannya. ${ }^{27}$

Kondisi yang menjadi syarat pencabutan izin adalah:

1. Pelaku usaha/kegiatan memindahtangankan izin usaha kepada pihak lain tanpa persetujuan tertulis dari pemberi izin.

2. Pelaku usaha/kegiatan tidak melaksanakan sebagian besar atau seluruh paksaan pemerintah dalam waktu yang ditentukan.

3. Usaha/kegiatan telah menyebabkan terjadinya pencemaran dan/ atau perusakan lingkungan pada tingkat yang membahayakan keselamatan dan kesehatan manusia. $^{28}$

4. Pelaku usaha/kegiatan tidak melaksanakan sebagian besar atau seluruh sanksi administratif yang

\footnotetext{
${ }^{24}$ Indonesia, Op. Cit., Undang-Undang Perlindungan dan Pengelolaan Lingkungan, Pasal 79.

${ }^{25}$ Indonesia, Op. Cit., Peraturan Menteri LH Nomor 2 tahun 2013, Lampiran I, hlm. 5.

${ }^{26}$ Ibid, Pasal 4 (4).

${ }^{27}$ Ibid, Lampiran I, hlm. 5.

${ }^{28}$ Ibid, Pasal 4 (5).
} 
Tentang Ekor yang Tak Lagi Beracun: Kritik Konseptual atas Sanksi Administratif dalam Hukum Lingkungan di Indonesia

telah diterapkan dalam waktu tertentu.

5. Usaha/kegiatan melakukan pelanggaran serius yang mengakibatkan pencemaran dan/atau kerusakan lingkungan hidup yang relatif besar dan menimbulkan keresahan masyarakat.

6. Usaha/kegiatan melakukan penyalahgunaan izin pembuangan air limbah untuk kegiatan pembuangan limbah B3.

7. Usaha/kegiatan melakukan penyimpanan, pengumpulan, pemanfaatan, pengolahan, dan penimbunan limbah B3 secara tidak sesuai sebagaimana yang tertuang dalam izin..$^{29}$

\section{Pemahaman Teoretis tentang Sanksi Administratif}

\section{A. Definisi Sanksi Administratif}

Van Wijk, et al. menguraikan unsurunsur sanksi administratif berikut. Pertama, sanksi administratif merupakan tindakan-tindakan yang membebani terhadap warga negara. Dalam konteks ini, van Wijk et al menyatakan bahwa pemberian insentif/disinsentif, perubahan standar/ baku mutu, pemberian kewajiban pembukaan informasi, atau tindakan pemerintah yang sifatnya umum, tidaklah termasuk ke dalam tindakan yang membebani dalam konteks sanksi administratif.
Kedua, sanksi dijatuhkan melalui sarana hukum publik. Dengan demikian, upaya hukum pemerintah melalui jalur hukum perdata, misalnya dalam rangka gugatan wanprestasi, tidak pula termasuk ke dalam konteks sanksi administratif. Ketiga, digunakan oleh pemerintah. Van Wijk, et al. mengartikan pemerintah di sini dalam arti luas, sehingga termasuk juga hakim dalam hal sanksi yang dijatuhkan berupa sanksi pidana) dan pejabat tata usaha negara $(\mathrm{TUN})^{30}$ dalam hal sanksi yang dijatuhkan berupa sanksi administratif. Keempat, sebagai reaksi atas ketidaktaatan. Menurut van Wijk, et al. sanksi administratif biasanya diberikan setelah adanya pelanggaran. Dengan demikian, berbagai tindakan pencegahan yang dibebankan oleh pejabat TUN biasanya tidak digolongkan ke dalam sanksi administratif. Meski demikian, para pengarang ini juga mengakui bahwa sanksi administratif berupa paksaan pemerintah atau uang paksa terkadang dapat pula diterapkan secara preventif. ${ }^{31}$

Salah satu yang membedakan sanksi administratif dengan sanksi menurut penegakan hukum perdata atau sanksi pidana adalah tidak diperlukannya kekuasaan pengadilan untuk menjatuhkan sanksi tersebut. Hal ini terlihat dari pandangan Oostenbrink, yang menyata-

${ }^{29}$ Ibid, Lampiran I, hal. 5.

${ }^{30}$ Istilah "Pejabat TUN" di sini digunakan dalam arti yang sama dengan pejabat pemerintah, pejabat administrasi negara.

${ }^{31}$ H.D. van Wijk, Op. Cit., hlm. 452. 
kan bahwa sanksi administratif adalah sanksi yang muncul dari hubungan antara pemerintah dengan warga negara, yang dilaksanakan tanpa perantaraan kekuasaan peradilan. ${ }^{32}$ Hal senada juga dikemukakan oleh Atmosudirjo yang menyatakan bahwa dalam penjatuhan sanksi administratif oleh pemerintah, pejabat TUN dapat langsung menjatuhkan sanksi tanpa perlu melalui perantaraan hakim. ${ }^{33}$

Menurut van den Brekel, et al., penegakan hukum administrasi negara dapat dilakukan dengan menggunakan tiga instrumen penegakan hukum, yaitu penegakan hukum secara administratif, pidana, dan perdata. ${ }^{34}$ Terkait penegakan hukum administratif, para pengarang ini juga menyatakan bahwa pejabat TUN diberikan kewenangan untuk melakukan penegakan hukum administratif dengan cara-cara yang diatur oleh hukum. Dalam konteks ini, sanksi administratif dijatuhkan melalui keputusan pejabat TUN, dan terhadapnya dibuka kemungkinan perlindungan hukum. ${ }^{35}$ Dengan demikian, pada satu sisi hukum memberikan kewenangan kepada pejabat TUN untuk menjatuhkan sanksi administratif, sedangkan pada sisi lain memberikan pula perlindungan hukum kepada publik agar terhindar dari penjatuhan sanksi yang dijatuhkan, misalnya, secara sewenang-wenang, tidak sesuai prosedur, atau dengan melanggar hukum.

Karena tidak memerlukan pihak ketiga (pengadilan) untuk menjatuhkannya, maka sanksi administratif dianggap lebih mudah dijatuhkan dan dikelola dibandingkan dengan sanksi lainnya. Berdasarkan pengalaman di Jerman, Faure menyatakan bahwa denda administratif jauh lebih mungkin diterapkan dibandingkan dengan sanksi pidana. Bahkan seandainya seorang pelanggar dinyatakan tidak bersalah oleh pengadilan pidana, tidak berarti bahwa sudah pasti tidak ada pelanggaran hukum apa pun dalam kasus tersebut. Karena itu, dalam kasus seperti ini pun masih terdapat kemungkinan bahwa sanksi administratif masih dapat dikenakan terhadap pelanggar tersebut. Oleh karena itu, menurut Faure, sanksi administratif akan lebih murah untuk diterapkan dan lebih memberikan efek "jera" (deterrent effect) dibandingkan dengan sanksi pidana. ${ }^{36}$

Kajian empiris di Kanada, sebagaimana dikemukakan oleh Macrory, mengonfirmasi lebih efektifnya sanksi ad-

\footnotetext{
${ }^{32}$ Ridwan HR, Op. Cit., hlm. 314. hlm. 41.

33 S. Prajudi Atmosudirjo, Hukum Administrasi Negara, Cet. 10 (Jakarta: Ghalia Indonesia, 1994),

${ }^{34}$ P.M. van den Brekel, E.M.J. Hardy, dan N.J.A.P.B. Niessen, Bestuursrecht (Den Haag: Boom Juridische uitgevers, 2007), hal. 118.

${ }^{35}$ Ibid.

${ }^{36}$ Michael Faure, "Effectiveness of Environmental Law: What Does the Evidence Tell Us," William E Mary Environmental Law and Policy Review, Vol. 36 No. 2 (2012), hlm. 324.
} 
ministratif dibandingkan dengan sanksi lainnya (pidana). Kajian tersebut membandingkan dua provinsi yaitu Ontario dan British Columbia. Di Ontario, sanksi yang tersedia adalah sanksi (denda) pidana, sedangkan di British Columbia sejak tahun 1979 telah diperkenalkan sanksi (denda) administratif. Kajian tersebut memperlihatkan bahwa meskipun rata-rata jumlah besaran denda yang dijatuhkan sama, tetapi jumlah pengawasan yang mengarah pada penjatuhan denda pidana di Ontario hanyalah setengah dari jumlah penjatuhan denda administratif di British Columbia. Sementara itu, jumlah banding terhadap sanksi pidana lebih banyak dari pada upaya hukum terhadap denda administratif. Kajian juga memperlihatkan bahwa diperlukan rata-rata 500 hari dari mulai pelanggaran sampai dengan penjatuhan sanksi pidana oleh pengadilan di Ontario, dan hanya 70 hari antara pelanggaran sampai dengan penjatuhan sanksi administratif di British Columbia. ${ }^{37}$

\section{B. Jenis Sanksi Administratif}

Berdasarkan sifatnya, sanksi administratif perlu dibedakan ke dalam sanksi yang bersifat perbaikan/pemulihan (herstelsancties), sanksi yang bersifat menghukum (bestraffende sancties), dan sanksi yang bersifat regresif (regressieve sancties).

\section{Sanksi yang Memulihkan (Her- stel-/Reparatoire Sancties)}

Van Wijk et al. menyatakan bahwa berdasarkan Pasal 5:2 Algemene wet bestruursrecht (selanjutnya disebut Awb) ${ }^{38}$ herstelsancties dapat merupakan "een bestuurlijke sanctie die strekt tot het geheel of gedeeltelijk ongedaan maken van een overtreding, tot het voorkomen van een overtreding, dan wel tot het wegnemen of beperken van de gevolgen van een overtreding". ${ }^{39}$ Artinya, sanksi ini dapat merupakan sanksi yang sebagian atau seluruhnya ditujukan untuk mengembalikan/memperbaiki pelanggaran, mencegah terjadinya pelanggaran, menghapuskan atau meminimalisasi akibat dari pelanggaran. Karena itu pula maka kelompok herstelsancties disebut juga dengan sanksi yang memperbaiki (reparatoir).

Menurut van den Brekel et al., herstelsancties adalah sanksi yang ditujukan untuk memulihkan pelanggaran hukum (gericht op herstel van de inbreuk op de rechtsorde). Contoh dari sanksi ini adalah perintah yang ditindaklanjuti dengan paksaan pemerintah (last onder bestuursdwang) dan perintah yang ditindaklanjuti dengan uang paksa (last onder dwang-

${ }^{37}$ Richard Macrory, "Environmental Sanctions," Environmental Policy and Law, Vol. 45 No. 6 (2015), hlm. 278.

${ }^{38}$ Awb adalah undang-undang di Belanda tentang ketentuan pokok hukum administrasi negara. Di dalam bahasa Inggris, Awb disebut sebagai General Administrative Law Act (GALA).

${ }^{39}$ H.D. van Wijk, Willem Konijnenbelt, dan Ron van Male, Op. Cit., hlm. 459.

${ }^{40}$ P.M. van den Breke, Niessen, Op. Cit., hlm. 118. 
som $) \cdot{ }^{40}$

\section{a. Last Onder Bestuursdwang (Perin- tah yang Ditindaklanjuti dengan Paksaan Pemerintah)}

Pasal 5:21 Awb menyatakan bahwa last onder berstuursdwang merupakan sanksi yang bertujuan untuk memulihkan, yang terdiri dari dua elemen, yaitu: Pertama, berupa sanksi yang memerintahkan dilakukannya perbaikan atas seluruh atau sebagian pelanggaran; dan kedua, adanya kewenangan pejabat TUN untuk melaksanakan sendiri perbaikan jika perintah perbaikan tidak dilaksanakan sama sekali atau tidak dilaksanakan secara tepat waktu. ${ }^{41}$ Last onder berstuursdwang memiliki dua elemen, yaitu elemen tindakan hukum berupa perintah kepada pelanggar untuk memperbaiki pelanggarannya, dan elemen tindakan nyata berupa pelaksanaan sendiri tindakan perbaikan jika perintah pemulihan tidak ditaati. Singkatnya, sanksi ini dapat diartikan sebagai perintah yang ditindaklanjuti dengan paksaan pemerintah (bestuursdwang). Dalam sanksi ini, apabila orang yang dikenakan sanksi ti- dak melaksanakan perintah perbaikan atau gagal melaksanakan perintah tersebut di dalam waktu yang ditentukan, maka pejabat TUN melaksanakan sendiri perintah perbaikan tersebut dengan biaya dari mereka yang dikenakan sanksi. ${ }^{42}$

Berangkat dari Pasal 5:21 Awb, van den Brekel et al., mendefinisikan paksaan pemerintah (bestuursdwang) sebagai "[h]et door feitelijk handelen door of vanwege een bestuursorgaan optreden tegen hetgeen in strijd met bij of krachtens enig wettelijk voorschrift gestelde verplichtingen is of wordt gedaan, gehouden of nagelaten. "43 Dalam pandangan van den Brekel tersebut, paksaan pemerintah merupakan tindakan nyata dari pemerintah terhadap pelanggaran peraturan perundang-undangan. Paksaan pemerintah di Belanda, terutama berbentuk tindakan nyata dan bukan merupakan tindakan hukum belaka. Dalam konteks paksaan pemerintah, tindakan pemerintah tidak terbatas hanya pada pemberian perintah, misalnya untuk memasang instalasi tertentu, tetapi terutama berupa tindakan nyata pemasangan instalasi tersebut oleh pemerintah. $^{44}$

${ }^{41}$ Pasal 5(21) Awb menyatakan:

"Onder last onder bestuursdwang wordt verstaan: de herstelsanctie, inhoudende: a) een last tot geheel of gedeeltelijk herstel van de overtreding, en b) de bevoegdheid van het bestuursorgaan om de last door feitelijk handelen ten uitvoer te leggen, indien de last niet of niet tijdig wordt uitgevoerd."

${ }^{42}$ Anonymous, "Sanction and Procedures Applicable to Breaches of the Legislation on Industrial Emissions in the Netherlands," Eastern and Central European Journal on Environmental Law, Vol. 16 No.1 (2012), hal. 59.

${ }^{43}$ P.M. van den Brekel, Niessen, Op. Cit., hlm. 122.

${ }^{44}$ Pandangan senada juga disampaikan oleh Hadjon, dkk yang menganggap bestuursdwang terutama sebagai tindakan nyata pemerintah guna mengakhiri suatu pelanggaran. Lihat: Philipus M. Hadjon, et al., Pengantar Hukum Administrasi Indonesia (Introduction to the Indonesian Administrative Law), cet. 10 (Yogyakarta: Gadjah Mada University Press, 2008), hlm. 246. 
Menurut Awb, elemen perintah di dalam sanksi ini harus menjelaskan tindakan perbaikan apa yang harus dilakukan oleh pelanggar. Perintah tersebut, harus menetapkan pula batas waktu bagi pelaksanaan perintah perbaikan. ${ }^{45}$ Perintah perbaikan juga harus diberitahukan kepada pelanggar, kepada orang-orang yang berhak atas penggunaan properti yang terkait dengan perintah perbaikan, dan kepada pihak ketiga yang memohon adanya penjatuhan sanksi. ${ }^{46}$ Elemen perintah ini dapat disimpangi jika terdapat keadaan mendesak. Dalam hal ini, Awb menyatakan bahwa dalam kasus mendesak, pejabat TUN yang memiliki kekuasaan untuk mengeluarkan perintah paksaan pemerintah dapat mengambil tindakan perbaikan tanpa didahului oleh adanya perintah perbaikan. ${ }^{47}$

Secara teoretis sanksi paksaan pemerintah tidak mensyaratkan adanya kekuasaan dan kemampuan dari pihak yang terkena sanksi untuk menjalankan perintah perbaikan yang dijatuhkan kepadanya. Hal ini karena seandainya pihak yang terkena sanksi tidak mampu menjalankan perbaikan yang diperintahkan, maka pemerintah yang akan melakukan sendiri perbaikan tersebut, dengan biaya dari orang yang terkena sanksi. ${ }^{48}$ Dalam menjatuhkan sanksi paksaan pemerintah, sanksi yang dijatuhkan perlu menjelaskan: aturan yang dilanggar; tindakan pemulihan/perbaikan yang harus dilakukan; periode di mana perbaikan/pemulihan harus dilakukan; dan besarnya biaya yang harus dikembalikan oleh penerima sanksi jika perbaikan/pemulihan dilakukan oleh pemerintah. ${ }^{49}$

Biaya untuk melakukan perbaikan dibebankan kepada pelanggar, kecuali jika ia tidak dapat diminta untuk menanggung biaya tersebut. Perintah perbaikan harus menjelaskan biaya perbaikan yang harus dibayar oleh pelanggar. Biaya ini meliputi pula biaya persiapan dilakukannya perbaikan oleh pemerintah dan penggantian biaya kompensasi atas kerugian yang ditimbulkan pelaksanaan paksaan pemerintah oleh pejabat TUN menurut Pasal 5(27).6. ${ }^{50}$

${ }^{45}$ disebut juga dengan "bestuursdwangbeschikking". P.M. van den Brekel, E.M.J. Hardy, dan N.J.A.P.B. Niessen, Op. Cit., hlm. 122.

${ }^{46}$ Pasal 5(24) Awb.

${ }^{47}$ Pasal 5(31) Awb.

${ }^{48}$ M.N. Boeve, et al., Omgevingsrecht, cet. 6 (Amsterdam: Europa Law Publishing, 2019), hlm. 398.

${ }^{49} \mathrm{Ibid}$.

${ }^{50}$ Pasal 5(25) Awb.

Terkait Pasal 5 (27).6 perlu dijelaskan bahwa pasal ini merupakan kewajiban pejabat TUN mengganti kerugian jika dalam tindakannya berupa memasuki suatu tempat, dalam rangka pelaksanaan paksaan pemerintah, ternyata menimbulkan kerugian. Dengan demikian, menurut Pasal 5:25 Awb ganti rugi yang harus dibayarkan ini dapat dimintakan penggantiannya (reimburse) kepada pihak pelanggar. 
Pejabat TUN yang melaksanakan tindakan nyata paksaan pemerintah (bestuursdwang) berwenang untuk memasuki suatu tempat sejauh yang diperlukan untuk pelaksanaan tugas mereka, ${ }^{51}$ menyegel bangunan, lokasi, dan apa pun yang berada di dalamnya, ${ }^{52}$ mengambil dan menyimpan barang yang diperlukan untuk tindakan penegakan hukum administratif, ${ }^{53}$ dan menjual barang yang disimpan dan diambilnya, apabila setelah 13 minggu barang tersebut tidak bisa dikembalikan. ${ }^{54}$

\section{b. Last Onder Dwangsom (Perintah yang Ditindaklanjuti dengan Uang Paksa)}

Menurut Awb, last onder dwangsom merupakan sanksi administratif yang pada satu berisi perintah kepada pelanggar untuk memperbaiki seluruh atau sebagian pelanggar; dan pada sisi lain mewajibkan pembayaran jika perintah perbaikan tidak dilakukan atau tidak dilakukan pada waktunya. ${ }^{55}$ Sanksi uang paksa ini terdiri dari dua elemen tindakan hukum yaitu perintah dari peja- bat kepada pelanggar untuk melakukan perbaikan dan penentuan pembayaran sejumlah uang (uang paksa) jika perintah perbaikan tidak dilaksanakan sama sekali atau tidak dilaksanakan tepat waktu. Selanjutnya, Awb menyatakan bahwa kewenangan untuk mewajibkan pembayaran ini berada di tangan pejabat TUN yang berwenang mengeluarkan perintah perbaikan. ${ }^{56}$ Singkatnya, sanksi ini adalah sanksi berupa perintah yang ditindaklanjuti dengan uang paksa (dwangsom).

Terkait elemen perintah reparasi dari last onder dwangsom, Awb menyatakan bahwa perintah tersebut harus menjelaskan tindakan perbaikan yang akan dilakukan, batas waktu dilakukannya perbaikan (untuk memperbaiki suatu pelanggaran atau untuk mencegah pelanggaran lebih lanjut), yang jika dilewati akan mengizinkan pejabat untuk meminta pembayaran uang paksa. ${ }^{57}$

Besarnya uang paksa (dwangsom) dapat ditentukan secara sekaligus (lump sum) atau dihitung per unit waktu keter-

${ }^{51}$ Pasal 5(27) Awb.

${ }^{52}$ Pasal 5(28) Awb.

${ }^{53}$ Pasal 5(29) Awb.

${ }^{54}$ Pasal 5(30) Awb.

${ }^{55}$ Pasal 5(31) d Awb menyatakan:

"Onder last onder dwangsom wordt verstaan: de herstelsanctie, inhoudende: a) een last tot geheel of gedeeltelijk herstel van de overtreding, en b) de verplichting tot betaling van een geldsom indien de last niet of niet tijdig wordt uitgevoerd."

${ }_{56}$ Pasal 5(32)1 Awb. Sementara itu, Pasal 5(32).2 Awb menyatakan bahwa pejabat TUN yang berwenang dapat memutuskan untuk tidak memberikan perintah pembayaran uang paksa jika hal ini justru bertentangan dengan kepentingan yang ingin dilindungi oleh aturan yang dilanggar.

${ }^{57}$ Pasal 5(32)a Awb. 
lambatan penaatan perintah perbaikan. ${ }^{58}$ Pejabat TUN harus menentukan jumlah maksimum uang paksa, yang secara proporsional dihitung berdasarkan beratringannya kepentingan yang dilanggar dan dampak dari adanya uang paksa tersebut. ${ }^{59}$ Beberapa pertimbangan terhadap proporsi uang paksa antara lain: keuntungan dari pelanggaran, seringtidaknya pelanggaran dilakukan, tipe pelanggaran, dan sifatnya (berat-ringannya pelanggaran). ${ }^{60}$

Van den Brekel, et al. menyatakan bahwa uang paksa merupakan alternatif dari paksaan pemerintah. Dengan uang paksa ini seorang pelanggar dipaksa untuk membayar sejumlah uang, sampai akhirnya ia menaati perintah. Oleh karena itu, uang paksa ini berfungsi untuk menghentikan pelanggaran, mencegah berlanjutnya atau diulangnya pelanggaran, dan mencegah terjadinya bahaya yang nyata dari pelanggaran. ${ }^{61}$

Selain itu, para pengarang ini juga mengetengahkan hal berikut. Pertama, uang paksa tidak diterapkan untuk kasus yang perlu penanganan mendesak. Kedua, besaran uang paksa harus proporsional dengan kepentingan yang dilanggar dan dengan tujuan penjatuhan sanksi. Ketiga, pembayaran uang paksa dapat ditentukan berdasarkan pembayaran sekaligus (ineens), pembayaran berdasarkan ukuran waktu lamanya pelanggaran (per tijdseenheid), atau pembayaran untuk tiap pelanggaran (per overtreding). Keempat, pejabat pemerintah harus menetapkan dengan jelas besarnya maksimum uang paksa, di mana besaran uang paksa ini setidaknya tidak boleh lebih kecil dibandingkan dengan keuntungan finansial dari pelanggaran. Terakhir, uang paksa tidak boleh dibuat dengan maksud untuk menghukum pelanggar. ${ }^{62}$

Terkait larangan untuk menghukum ini, Boeve, dkk. membandingkan antara paksaan pemerintah dengan uang paksa dilihat dari sisi kemampuan penerima sanksi untuk menjalankan perintah perbaikan/pemulihan. Paksaan pemerintah tidak mensyaratkan adanya kemampuan penerima sanksi (pelanggar) untuk melaksanakan perintah, sedangkan uang paksa mensyaratkan adanya kemampuan penerima sanksi untuk melaksanakan perintah. Dalam hal ini, jika penerima sanksi bukanlah pihak yang memiliki kekuasaan untuk melaksanakan perintah perbaikan/pemulihan, maka pembayaran yang dibebankan kepadanya bukan lagi bersifat pemulihan (reparatoir), tetapi

\footnotetext{
${ }^{58}$ Pasal 5(32)b.1 Awb.

${ }^{59}$ Pasal 5(32)b.2-3 Awb

${ }^{60}$ Anonymous, Op. Cit., hlm. 58.

${ }^{61}$ Van den Brekel, et. al., Op. Cit., hlm. 122-123.

${ }^{62}$ Ibid., hlm. 123.
} 
bersifat menghukum (punitief). ${ }^{63}$ Seperti diutarakan sebelumnya, uang paksa tidak boleh bersifat menghukum.

\section{Sanksi yang Menghukum (Bes- traffende/Punitieve Sancties)}

Terkait sanksi yang bersifat menghukum, Pasal 5:2 ayat (1) huruf c dari Awb menyatakan bahwa sanksi yang menghukum adalah "een bestuurlijke sanctie voor zover deze beoogt de overtreder leed toe te voegen", sanksi administratif yang ditujukan untuk menambah penderitaan bagi pelanggar. Contoh dari sanksi ini adalah denda administratif (bestuurlijke/ administratieve boete). ${ }^{64}$ Misalnya apabila seseorang terlambat membayar pajak, di samping harus membayar hutang pajaknya, orang tersebut harus membayar sejumlah uang tambahan. Uang tambahan inilah yang disebut denda dan dapat dikatakan sebagai bentuk hukuman. ${ }^{65}$

Menurut Heldeweg dan Seerden, sanksi punitif dijatuhkan bukan untuk memaksa pelanggar agar menghentikan pelanggarannya, tetapi semata-mata dijatuhkan karena seseorang telah melaku- kan perbuatan yang melanggar hukum. Dengan alasan penjatuhan sanksi seperti ini, maka secara teoretis sanksi akan tetap dijatuhkan bahkan ketika pelanggar memperbaiki perilakunya, misalnya menghentikan pelanggaran. ${ }^{66}$
a. Denda Administratif (Bestuurlijke Boete)

Pasal 5:40 ayat (1) Awb menyatakan bahwa denda administratif merupakan pembebanan kewajiban tanpa syarat untuk melakukan pembayaran sejumlah uang. Sementara itu, Pasal 5:40 ayat (2) menyatakan bahwa ketentuan ini tidak berlaku bagi pencabutan atau pengubahan keputusan bantuan keuangan yang telah diterbitkan sebelumnya. ${ }^{67}$

Istilah tanpa syarat ("onvoorwaardelijke") di sini berarti bahwa, berbeda dari uang paksa, kewajiban pembayaran uang ini tetap ada terlepas dari apakah pelanggar telah memperbaiki perilakunya atau tidak. Pembayaran uang di dalam denda ditujukan untuk menghukum pelanggar, bukan untuk mendorong pelanggar untuk melakukan perbaikan/

${ }^{63}$ M.N. Boeve, et al., Op. Cit., hlm. 400.

${ }^{64}$ Van den Brekkel., et. al., Op. Cit., hal. 119.

${ }^{65}$ H.D. van Wijk, Willem Konijnenbelt, dan Ron van Male, Op. Cit., hlm. 459.

${ }^{66}$ Michiel A. Heldeweg dan René J.H.G. Seerden, Environmental Law in the Netherlands (Alphen aan den Rijn: Wolters Kluwer, 2012), hal. 195.

${ }^{67}$ Pasal 5(40) Awb menyatakan:

"Onder bestuurlijke boete wordt verstaan: de bestraffende sanctie, inhoudende een onvoorwaardelijke verplichting tot betaling van een geldsom.

Deze titel is niet van toepassing op de intrekking of wijziging van een aanspraak op financiële middelen."

Untuk ulasan pasal ini, lihat misalnya: T. Barkhuysen, et al., Bestuursrecht in het Awb-tijdperk (Deventer: Wolters Kluwer, 2018), hal., 191. 
pemulihan. ${ }^{68} \mathrm{Di}$ sinilah letak perbedaan utama antara uang paksa dengan denda. Apabila kewajiban pembayaran dalam uang paksa akan hilang manakala si pelanggar telah melaksanakan perintah perbaikan/pemulihan, di dalam denda kewajiban pembayaran tetap ada seandainya pun pelanggar telah melakukan perbaikan/pemulihan.

Awb menentukan bahwa denda administratif tidak bisa dijatuhkan jika pelanggar tidak bisa dimintakan pertanggungjawaban, ${ }^{69}$ telah meninggal dunia, ${ }^{70}$ dan telah dijatuhi denda administratif lain untuk pelanggaran yang sama atau pejabat TUN sebelumnya telah memberikan pemberitahuan bahwa pelanggaran tersebut tidak akan dijatuhi sanksi denda administratif, ${ }^{71}$ untuk pelanggaran yang sama telah dimulai proses peradilan pidana, atau telah ada sanksi pidana, ${ }^{72}$ atau telah melawati masa kedaluwarsa yaitu 5 tahun sejak adanya pelanggaran. ${ }^{73}$

Selain itu, Awb menyatakan bahwa nilai maksimum dari denda administratif dapat ditentukan di dalam pera- turan perundang-undangan spesifik/ sektoral. ${ }^{74}$ Apabila nilai denda tidak ditentukan dalam peraturan perundangundangan, maka pejabat TUN menentukan jumlah denda dengan memperhatikan tingkat keseriusan pelanggaran dan sejauh mana pelanggar dapat dimintakan pertanggungjawaban. Pejabat TUN dapat pula memperhatikan situasi ketika pelanggaran dilakukan. ${ }^{75}$ Pejabat TUN juga dapat menentukan nilai denda yang lebih rendah dari peraturan perundangundangan apabila terdapat alasan untuk menganggap nilai denda menurut peraturan perundang-undangan terlalu tinggi. ${ }^{76}$

Sebelum denda dijatuhkan, terlebih dahulu harus ada laporan mengenai pelanggaran, yang memuat informasi tentang nama pelanggar, jenis pelanggaran dan aturan yang dilanggar, serta waktu dan tempat terjadinya pelanggaran. ${ }^{77}$ Laporan atas pelanggaran ini harus dikirimkan kepada pelanggar. ${ }^{78}$ Sebelum sanksi dijatuhkan, pelanggar diberikan kesempatan untuk meneliti informasi yang ada di dalam laporan, pembelaan

\footnotetext{
${ }^{68}$ Anonymous, Op. Cit., hal. 59.

${ }^{69}$ Pasal 5(41) Awb.

70 Pasal 5(42) Awb.

${ }^{71}$ Pasal 5(43) jo. Pasal 5(50)2a. Awb.

72 Pasal 5(44) Awb.

${ }^{73}$ Pasal 5(45) Awb.

74 Pasal 5(46)1. Awb.

${ }^{75}$ Pasal 5(46)2. Awb.

${ }^{76}$ Pasal 5(46)3. Awb.

77 Pasal 5(48)1 dan 2 Awb.

${ }^{78}$ Pasal 5(48)3 Awb.
} 
diri, dan pendapat atas laporan pelanggaran dan rencana penjatuhan sanksi. ${ }^{79}$ Selanjutnya, dalam waktu 13 minggu sejak adanya laporan dan setelah adanya pembelaan diri dari pelanggar, pejabat TUN dapat mengeluarkan keputusan untuk menjatuhkan sanksi administratif atau tidak. ${ }^{80}$ Sanksi administratif yang dijatuhkan tersebut memuat nama pelanggar dan jumlah denda yang dijatuhkan. ${ }^{81}$ Prosedur ini berlaku pula untuk sanksi administratif yang bersifat punitif lainnya, sepanjang dimungkinkan oleh peraturan perundang-undangan terkait. $^{82}$

\section{b. Sanksi Punitif Lainnya}

Selain denda, Neerhof menyebut beberapa bentuk sanksi administratif lain yang juga bersifat punitif. Sanksi ini dapat berupa pencabutan atau pembekuan sementara keputusan yang menguntungkan. ${ }^{83}$ Selain itu, Neerhof juga menyebutkan berbagai sanksi disiplin bagi pegawai negeri sebagai sanksi punitif. ${ }^{84}$ Namun demikian, oleh pengarang lain, pembekuan izin ini dikelompokkan ke dalam sanksi yang bersifat regresif, sedangkan sanksi disiplin digolongkan kepada sanksi administratif "lainnya". Apakah sanksi ini pada akhirnya akan bersifat punitif atau tidak, akan tergantung pada tujuan dikeluarkannya sanksi tersebut.

\section{Sanksi yang Bersifat Regresif (Regressive Sancties)}

Untuk sanksi yang bersifat regresif, van den Brekel dkk menyatakan bahwa sanksi ini bertujuan untuk mengembalikan ke kondisi seperti sebelum terjadinya kondisi hukum yang menguntungkan. ${ }^{85}$ Contohnya, pencabutan atau perubahan keputusan yang menguntungkan misalnya pencabutan izin. Dalam hal ada pencabutan keputusan, maka kon-

\footnotetext{
${ }^{79}$ Pasal 5(49) dan 5(50) Awb.

${ }^{80}$ Pasal 5(51)1 Awb.

${ }^{81}$ Pasal 5(52) Awb.

${ }^{82}$ Pasal 5(54) Awb.
}

${ }^{83}$ Seperti izin penyiaran, izin mengemudi taxi, dan izin penangkapan ikan. A.R. Neerhof, "Bestraffende Sancties", dalam: L.J.A. Damen, et al. (eds.), Bestuursrecht Deel I: Systeem, Bevoegdheid, Bevoegdheidsuitoefening, Handhaving, 2de druk (Den Haag: Boom Juridische uitgevers, 2005b). Sebagai perbandingan, dalam konteks Eropa, de Moor-van Vugt menjelaskan beberapa contoh jenis sanksi bersifat menghukum, yaitu: a). pembayaran denda administratif; b). pembayaran sejumlah uang yang lebih besar dari pendapat yang diperoleh melalui pelanggaran; c). penghilangan sebagian atau seluru keuntungan dari adanya pelanggaran; d). pengecualian atau pencabutan keuntungan tertentu yang sebelumnya telah diperoleh; e). penghentian sementara dari skema bantuan pemerintah; f). diambilnya uang jaminan tertentu oleh pemerintah; dan g). sanksi lainnya yang bersifat ekonomi. Lihat: Adrienne de Moor-van Vugt, "Administrative Sanctions in EU Law," Review of European Administrative Law, Vol. 5 No. 1 (2012), hlm. 13.

${ }^{84} \mathrm{Ibid}, \mathrm{hlm} .696-697$.

${ }^{85}$ Dalam Bahasa Belanda: "[t]erugkeer naar de oorspronkelijke rechtstoestand". P.M. van den Brekel, E.M.J. Hardy, dan N.J.A.P.B. Niessen, Op. Cit., hlm. 119. 
Tentang Ekor yang Tak Lagi Beracun: Kritik Konseptual atas Sanksi Administratif dalam Hukum Lingkungan di Indonesia

disi hukum dikembalikan ke kondisi seperti sebelum dikeluarkannya keputusan yang menguntungkan.

Dalam konteks lingkungan hidup, Heldeweg dan Seerden mengatakan bahwa sanksi pencabutan keputusan yang menguntungkan bisa dijatuhkan apabila pejabat menemukan beberapa kondisi berikut ini: 86

a) Ada pernyataan yang tidak benar yang berkaitan dengan dasar dari dikeluarkannya izin.

b) Tidak melakukan perbuatan yang sesuai dengan izin.

c) Tidak melakukan perbuatan yang sesuai dengan persyaratan izin atau ketentuan di dalam izin.

d) Tidak melakukan perbuatan yang berkaitan dengan peraturan perundang-undangan yang berlaku bagi pemegang izin.

Dalam pandangan Broring dan Keulen, pencabutan izin merupakan sanksi yang bersifat memperbaiki (reparatoir). Kedua pengarang ini menolak pencabutan izin dikatakan sebagai sanksi punitif. Menurutnya, pencabutan izin hanya akan bersifat punitif jika hal itu secara tegas disebutkan bahwa sanksi tersebut dimaksudkan sebagai penambah penderitaan bagi mereka yang melanggar. ${ }^{87}$
Hal ini berarti bahwa pencabutan izin pada dasarnya tidak boleh dijatuhkan melebihi tindakan yang secara proporsional dapat memperbaiki/memulihkan pelanggaran. Pandangan di atas juga dikemukakan oleh Boeve, dkk, yang menganggap bahwa karena pencabutan izin merupakan sanksi yang memperbaiki (reparatoir), maka sanksi ini hanya dapat dijatuhkan jika sebelumnya telah diberikan kepada pelanggar untuk melakukan penaatan terhadap peraturan atau menghentikan pelanggaran dalam kurun waktu tertentu. ${ }^{88}$

Sementara itu, Van den Brekel, dkk menyatakan bahwa sanksi pencabutan keputusan yang menguntungkan dapat bersifat memulihkan (reparatoir) atau menghukum (punitif). ${ }^{89}$

Dari uraian di atas terlihat bahwa pencabutan keputusan yang menguntungkan adalah pengembalian keadaan ke keadaan sebelum keputusan yang menguntungkan diberikan. Sanksi jenis ini dapat bersifat reparatoir atau punitive. Pada satu sisi, sifat reparatoir terlihat jika sanksi pencabutan keputusan diberikan karena ada informasi tidak benar yang diberikan oleh penerima keputusan yang menguntungkan. Seandainya informasi

${ }^{86}$ Michiel A. Heldeweg dan René J.H.G. Seerden, Op. Cit., hlm. 194.

${ }^{87}$ H.E. Broring dan B.F. Keulen, Bestraffende Sancties in het Strafrecht en het Bestuursrecht (Zutphen: Uitgeverij Paris, 2017), hlm. 61-62.

${ }^{88}$ M.N. Boeve, et al., Op. Cit., hlm. 404.

89 "...[v]oorbeeld herstelsancrie: intrekking omdat de begunstigende beschikking is verkregen op basis van onjuistegegevens. Op basis van de juistegegevens zou de beschikking niet zijn verleend."P.M. van den Brekel, E.M.J. Hardy, dan N.J.A.P.B. Niessen, Op. Cit., hal. 125. 
tersebut diketahui sejak awal, keputusan yang menguntungkan tersebut tidak akan diberikan. Pencabutan keputusan juga bisa bersifat reparatoir jika pencabutan dilakukan semata-mata untuk dihentikannya pelanggaran atau dampak dari pelanggaran, dan bukan pada penambahan penderitaan dari pelanggar. ${ }^{90}$

Namun demikian, pencabutan keputusan dapat bersifat punitif jika ditunjukkan untuk menghukum pelanggar. Menurut van den Brekel, dkk, hal ini terjadi jika pencabutan dilakukan karena adanya ketidaktaatan terhadap syarat perizinan atau peraturan. ${ }^{91}$

Sementara itu, Heldeweg dan Seerden berpendapat bahwa sanksi pencabutan keputusan menjadi bersifat reparatoir apabila pencabutan ini ditujukan sepenuhnya untuk memulihkan kondisi hukum ke kondisi semula sehubungan dengan adanya ketidaktaatan terhadap izin. Misalnya, pada saat pemegang izin tidak mematuhi persyaratan di dalam izin, pencabutan izin ditujukan untuk mengoreksi ketidakpatuhan ini. Dalam arti bahwa melalui pencabutan izin, perilaku ketidaktaatan terhadap izin dikoreksi dengan mencabut izin atas kegiat- an, sehingga seluruh kegiatan menjadi tidak boleh lagi dikerjakan. Pada sisi lain, sanksi pencabutan keputusan menjadi bersifat punitif apabila pencabutan ini ditujukan untuk menghukum pelanggar atau menciptakan bahaya bagi pelanggar. Contohnya adalah sanksi pencabutan izin atas dilakukannya tindakan di luar apa yang diizinkan. Menurut Heldeweg dan Seerden, pencabutan izin dalam konteks ini ditujukan bukan untuk mengoreksi perbuatan yang melanggar dan mengembalikan kondisi hukum ke kondisi sebelum terjadinya pelanggaran, tetapi untuk menghukum pemegang izin dengan mencabut hak untuk melakukan perbuatan tertentu yang dimilikinya. ${ }^{92}$

Artikel ini melihat bahwa sebenarnya sulit untuk menentukan sifat mana yang lebih dominan di dalam sanksi pencabutan keputusan yang menguntungkan ini. Dalam satu kasus, sanksi regresif seperti pencabutan izin dapat bersifat reparatoir, namun dalam kasus lain dapat bersifat punitif. Karena sanksi regresif dapat bersifat reparatoir atau punitif, maka sanksi ini dikelompokkan tersendiri, terpisah baik dari sanksi reparatoir maupun punitif.

90 "..wettelijke of vergunningsvoorschriften zijn overtreden, het karakter van een herstelsanctie voorzover zij zuiver zijn gericht op beeindiging of het ongedaan maken van de overtreding of de gevolgen daarvan, dan wel op het voorkomen van herhaling van de overtreding, en niet mede tot doel hebben om de overtreder leed toe te voegen." A.R. Neerhof, "Herstelsancties”, dalam: L.J.A. Damen, et al. (eds.), Bestuursrecht Deel 1: Systeem, Bevoegdheid, Bevoegdheidsuitoefening, Handhaving, 2de druk (Den Haag: Boom Juridische uitgevers, 2005a), hlm. 670-671.

${ }^{91}$ Dalam Bahasa Belanda: "wettelijke of beschikkingsvoorschriften niet worden nageleifd". P.M. van den Brekel, E.M.J. Hardy, dan N.J.A.P.B. Niessen, Op.Cit. hlm. 125.

${ }^{92}$ Michiel A. Heldeweg dan René J.H.G. Seerden, Op. Cit., hlm. 194. 
Tentang Ekor yang Tak Lagi Beracun: Kritik Konseptual atas Sanksi Administratif dalam Hukum Lingkungan di Indonesia

Pencabutan keputusan yang menguntungkan akan bersifat reparatoir apabila pejabat melihat bahwa pemegang izin sebenarnya tidak layak memperoleh izin ${ }^{93}$ atau sudah tidak ada kemungkinan untuk menaati persyaratan atau kewajiban di dalam izin. Dengan demikian, dalam konteks ini pencabutan keputusan dapat saja dilakukan setelah penilaian yang mendalam atas pelanggaran sebelumnya dan sanksi lebih ringan yang sebelumnya telah dijatuhkan. ${ }^{94}$

Sedangkan, pencabutan keputusan menjadi bersifat menghukum apabila tujuan pencabutan ini bukan karena pemegang izin dianggap sudah tidak mampu lagi untuk taat terhadap izin, tetapi karena pemegang izin sudah melakukan sesuatu di luar yang diizinkan. Sifat menghukum dari pencabutan keputusan ini dijatuhkan jika pemegang izin memperoleh keuntungan dari perbuatan di luar yang diizinkan, atau terdapat kerugian dari perbuatan melawan hukum pemegang izin tersebut. Pencabutan keputusan yang bersifat punitif dijatuhkan dalam proses yang lebih singkat dibandingkan dengan pencabutan keputusan yang bersifat reparatoir, serta untuk pelanggaran yang lebih serius dan lebih mengarah pada penyalahgunaan izin.

\section{Sanksi Administratif Lainnya}

Beberapa pengarang mengelompokkan beberapa sanksi administratif ke dalam andere bestuurlijke sancties, sanksi administratif lainnya, karena dianggap tidak cocok dengan sifat sanksi administratif yaitu reparatoir atau punitif. Oleh karena itu, terhadap sanksi lainnya tersebut perlu ada penelusuran lagi apakah sanksi tersebut bersifat punitif atau tidak. ${ }^{95}$ Salah satu jenis sanksi lainnya yang dikemukakan van den Brekel adalah pengambilan uang jaminan (waarborgsom) ${ }^{96}$

Pasal 8.15 Wet Miliebeheer tahun $1993^{97}$ (disingkat Wm yaitu UU Penge-

\footnotetext{
${ }^{93}$ misalnya karena didasarkan pada informasi yang tidak benar.

${ }^{94}$ Namun demikian, perlu dicatat pula pandangan Neerhof yang sepertinya tidak begitu setuju dengan pernyataan bahwa pencabutan keputusan yang menguntungkan memiliki sifat reparatoir. Pengarang ini menolak pandangan yang menganggap bahwa pencabutan keputusan bersifat reparatoir karena pencabutan didasarkan pada ketidakmampuan penerima keputusan untuk memenuhi persyaratan yang muncul karena penerima keputusan memiliki hubungan tertentu dengan pejabat TUN. Menurut Neerhof, hubungan antara penerima keputusan dengan pejabat TUN tidak lah berpengaruh pada penjatuhan sanksi berupa pencabutan keputusan yang menguntungkan. Sanksi semacam ini dijatuhkan karena adanya perilaku yang dianggap tidak benar dan melanggar hukum, sehingga perbaikan perilaku dan akibat dari pelanggaran tidak ada kaitannya dengan penjatuhan sanksi ini. Dengan kata lain, Neerhof sepertinya melihat sanksi jenis ini lebih bersifat punitief. Lihat: A.R. Neerhof (2005a), op cit., hal. 671-672.

${ }^{95}$ H.D. van Wijk, Willem Konijnenbelt, dan Ron van Male, Hoofdstukken van Bestuursrecht (Den Haag: Elsevier Juridisch, 2008), hlm. 488.

${ }^{96}$ Van Den Brekel, et al., Op. Cit., hlm. 126.

${ }^{97}$ Pasal 8.15 Wm sudah tidak berlaku sejak 1 Oktober 2010.
} 
lolaan Lingkungan) menyatakan bahwa pemerintah menetapkan bahwa kategori kegiatan/usaha tertentu yang berpotensi menimbulkan dampak serius pada lingkungan hidup harus dilengkapi dengan izin (otorisasi), yang juga berarti bahwa kegiatan/usaha tersebut harus memiliki dua jenis jaminan keuangan. Jaminan pertama adalah jaminan keuangan untuk menjamin penaatan atas kewajiban di dalam izin. Jaminan kedua adalah jaminan keuangan atas pertanggungjawaban perdata jika kegiatan/usaha tersebut menimbulkan kerugian. ${ }^{98}$ Selanjutnya, jika pemegang izin gagal melaksanakan kewajiban menurut izin, maka pemerintah dapat berapa banyak jaminan keuangan jenis pertama, yaitu yang berfungsi sebagai uang jaminan ketaatan, yang akan diambil oleh pemerintah. ${ }^{99}$

\section{Kumulasi Sanksi}

Menurut Awb, pejabat administrasi tidak boleh menjatuhkan beberapa sanksi yang bersifat memulihkan (herstelsancties) untuk satu pelanggaran yang sama. ${ }^{100}$ Namun demikian, secara hukum masih diperbolehkan adanya penjatuhan sanksi yang bersifat memulihkan bersama-sama dengan sanksi yang bersifat menghukum untuk pelanggaran yang sama. Artinya, secara hukum tidak dimungkinkan adanya kumulasi sanksi administratif yang sama-sama bersifat memulihkan (herstelsancties), tapi masih dimungkinkan adanya kumulasi antara herstelsancties dengan bestraffende sancties. ${ }^{101}$

Dengan kata lain, sanksi administratif yang memiliki tujuan/fungsi sama tidak boleh dijatuhkan bersama-sama. Misalnya, untuk pelanggaran yang sama

${ }^{98}$ Wm Pasal 8.15 ayat 1 menyatakan:

"Bij algemene maatregel van bestuur wordt bepaald dat in daarbij aangegeven categorieën van gevallen waarin inrichtingen ernstige nadelige gevolgen voor het milieu kunnen veroorzaken, aan de vergunning tevens voorschriften kunnen worden verbonden, die de verplichting inhouden dat degene die de inrichting drijft:

financiële zekerheid stelt voor het nakomen van krachtens de vergunning voor hem geldende verplichtingen;

financiële zekerheid stelt ter dekking van zijn aansprakelijkheid voor schade die voortoloeit uit door de inrichting veroorzaakte nadelige gevolgen voor het milieu."

${ }^{99} \mathrm{Wm}$ Pasal 8.15 ayat 4 menyatakan:

"Indien overeenkomstig het eerste lid een voorschrift als bedoeld in dat lid, onder a, aan een vergunning is verbonden, kan het bevoegd gezag bij het niet nakomen door de houder van de vergunning van een krachtens de vergunning voor hem geldende verplichting waarvoor financiële zekerheid is gesteld, bepalen tot welk bedrag het verhaal zal nemen op de gestelde zekerheid."

Jaminan semacam ini dalam teori hukum lingkungan dikelompokkan ke dalam deposit refundable system atau disebut juga performance bond. Di Indonesia, hal ini dapat ditemukan dalam jaminan reklamasi. Lihat: PP Nomor 46 tahun 2017 tentang Instrumen Ekonomi Lingkungan Hidup, Pasal 20 ayat (1) huruf a, dan Penjelasannya.

100 " $[$ h]et bestuursorgaan legt geen herstelsanctie op zolang een andere wegens dezelfde overtreding opgelegde herstelsanctie van kracht is".Pasal 5(6) Awb.

${ }^{101}$ Van Den Brekel, et al., Op. Cit., hlm. 128. 
Tentang Ekor yang Tak Lagi Beracun: Kritik Konseptual atas Sanksi Administratif dalam Hukum Lingkungan di Indonesia

tidak boleh dijatuhkan sanksi paksaan pemerintah dan uang paksa secara bersama-sama; tetapi boleh menjatuhkan paksaan pemerintah plus denda administratif, atau uang paksa plus denda administratif.

\section{Persoalan Konseptual yang Fatal}

UUPPLH dan turunannya ternyata secara konseptual bermasalah dalam memahami sanksi administratif, terutama paksaan pemerintah, denda, dan uang paksa. Persoalan konseptual ini pada gilirannya berpotensi untuk menggerus fungsi efek jera dari sanksi administratif.

\section{A. Pemahaman Keliru tentang Pak- saan Pemerintah}

Rumusan UUPPLH maupun PermenLH Nomor 2 Tahun 2013 mengenai paksaan pemerintah mengindikasikan bahwa paksaan pemerintah hanya merupakan perintah untuk melakukan perbuatan tertentu, tanpa disertai adanya kemungkinan bahwa pemerintah akan melakukan sendiri apa yang diperintahkan jika dalam waktu tertentu pelanggar gagal melaksanakan perintah tersebut.

Alih-alih melakukan sendiri perintah pemulihan/perbaikan, UUPPLH justru memberikan wewenang kepada pemerintah untuk memberikan sanksi lainnya apabila pelanggar gagal memenuhi perintah pemulihan/perbaikan. UUPPLH memberikan tiga kemungkinan bagi pemerintah untuk memberikan respons apabila pelanggar/penerima sanksi tidak melakukan apa yang diperintahkan. Pertama, pemerintah dapat menjatuhkan sanksi pembekuan atau pencabutan izin. ${ }^{102}$ Kedua, pemerintah dapat memilih untuk memberikan "denda". ${ }^{103}$ Ketiga, pemerintah dapat menuntut untuk membawa pelanggar/penerima sanksi secara pidana. ${ }^{104}$

Hal yang sama juga dapat dilihat dalam PermenLH Nomor 2 Tahun 2013, yang mengatur bahwa respons pemerintah atas tidak dilaksanakannya perintah adalah pembekuan izin, ${ }^{105}$ pencabutan izin, ${ }^{106}$ dan "denda administratif" ${ }^{107}$

Konsep UUPPLH dan PermenLH mengenai paksaan pemerintah memperlihatkan bahwa paksaan pemerintah dalam hukum lingkungan di Indonesia dimaknai hanya sebatas dikeluarkannya perintah kepada pelanggar untuk melakukan perbuatan tertentu, tanpa disertai ancaman bahwa apabila pelanggar

${ }^{102}$ Indonesia, Op. Cit., Undang-Undang Perlindungan dan Pengelolaan Lingkungan Hidup, Pasal 79.

${ }^{103}$ Ibid, Pasal 81.

${ }^{104}$ UUPPLH mengancam penanggung jawab usaha/kegiatan yang tidak melaksanakan paksaan pemerintah dengan ancaman pidana penjara 1 tahun dan denda Rp 1 Milyar. Lihat: UU Nomor 32 tahun 2009, Pasal 114.

${ }^{105}$ Indonesia, Op. Cit., Peraturan Menteri LH Nomor 2 tahun 2013,, Pasal (4).

${ }^{106}$ Ibid., ayat (5).

${ }^{107}$ Ibid., Pasal 6. 
tidak melaksanakan perintah tersebut, pemerintah lah yang akan melaksanakan perintah, dengan biaya dari pelanggar. Uniknya, meskipun dalam kenyataannya paksaan pemerintah tidak lebih dari sekadar tindakan hukum, namun PermenLH menyatakan bahwa paksaan pemerintah ini adalah tindakan nyata untuk menghentikan pelanggaran atau memulihkan keadaan ke kondisi semula. ${ }^{108}$ Karenanya, dapat dikatakan bahwa peraturan di Indonesia bukan hanya keliru memahami paksaan pemerintah, tetapi juga memiliki pandangan yang tidak koheren. Di satu sisi disebutkan bahwa paksaan pemerintah adalah tindakan nyata, tetapi di sisi lain uraian paksaan pemerintah justru hanya memuat perintah tanpa disertai tindakan nyata. ${ }^{109}$

${ }^{108}$ Ibid., Lampiran I, hlm. 4.

${ }^{109}$ Sebagai perbandingan, perhatikan contoh paksaan pemerintah di Belanda, sebagaimana dikemukakan oleh Boeve, dkk, di bawah ini:

"Wij gelasten woningcorporatie X ... tot het verwijderen en verwijderd houden van alle woonboten van woningcorporatie $X$, welke zijn gelegen aan de IJdijk (nrs $a, b, c$, d, enz.) uit de wateren van stadsdeel Zeeburg binnen zes weken na dagtekening van dit besluit. Indien aan deze last geen gehoor wordt gegeven, dan zullen alle aan de IJdijk gelegen woonboten van woningcorporatie X...op kosten en voor risico van de overtreder naar de Bewaarhaven worden versleept."

Lihat: M.N. Boeve, et al., Op., Cit., hlm. 399.

Contoh paksaan pemerintah tersebut menerangkan bahwa pemerintah kota memerintahkan perusahaan $X$ untuk memindahkan semua rumah perahu yang berlokasi di IJdijk dengan nomor rumah a, b, c, d, dst, di daerah Zeeburg. Perusahaan diberi waktu enam minggu untuk melakukan pemindahan tersebut. Jika perintah pemindahan tersebut tidak dipenuhi, maka pemerintah akan memindahkan (menyeret) rumah perahu tersebut ke daerah Bewaarhaven, dengan biaya dan risiko ditanggung oleh perusahaan.

Contoh di atas memperlihatkan bahwa paksaan pemerintah di Belanda tidak hanya akan berisi perintah, yaitu perintah untuk memindahkan rumah perahu. Sanksi tersebut juga disertai kemungkinan bahwa pemerintah akan melakukan sendiri pemindahan tersebut apabila penerima sanksi (pelanggar) tidak melakukan pemindahan dalam waktu tertentu.

${ }^{110}$ Ibid., Lampiran I, hal. 5. 
kan sebagai hukuman atas pelanggaran, tetapi reaksi atas tidak dilaksanakannya sanksi perintah kepada pelanggar untuk melakukan perbuatan tertentu. ${ }^{111}$ Jika pelanggar/penerima sanksi telah melakukan apa yang diperintahkan kepadanya, maka pelanggar/penerima sanksi tidak perlu lagi dibebankan kewajiban membayar sejumlah uang. Hal ini menunjukkan bahwa sanksi yang dimaksud sebenarnya bukanlah ditujukan sebagai hukuman, tetapi sebagai upaya untuk mendorong pelanggar/penerima sanksi memperbaiki keadaan dan menghentikan pelanggarannya. Secara singkat, rumusan tersebut tidak dapat dikatakan sebagai denda administratif (bestuurlijke boete), tetapi lebih tepat disebut uang paksa (dwangsom). ${ }^{112}$

\section{Kekeliruan yang Berpotensi Menurunkan Efektivitas Sanksi Administratif}

Uraian di atas menimbulkan konsekuensi berikut. Pertama, pelanggaran hukum lingkungan di Indonesia hanya akan dikenakan sanksi berupa perintah untuk melakukan perbuatan tertentu, tanpa adanya kemungkinan bahwa perintah tersebut akan dipaksakan dengan dilakukan sendiri oleh pemerintah atas biaya dan risiko dari pelanggar/penerima sanksi. Kedua, pelanggaran hukum lingkungan juga tidak akan dikenakan sanksi administratif yang bersifat menghukum, yaitu denda. Kedua kekeliruan konseptual ini berpotensi mengebiri daya guna dari sanksi administratif. Menghilangkan racun dari ekor hukum

111 Seperti telah dikemukakan sebelumnya, hal ini dinyatakan sebagai pembayaran atas tidak dilaksanakannya paksaan pemerintah. Hal ini merupakan kekeliruan, karena secara teoretis sebenarnya tidak mungkin paksaan pemerintah tidak dilaksanakan. Secara teoretis, paksaan pemerintah berarti apabila pelanggar/penerima sanksi tidak melaksanakan apa yang diperintahkan, maka pemerintah sendiri lah yang akan melaksanakan perintah tersebut atas biaya dan risiko dari pelanggar/penerima sanksi.

112 Untuk menunjukkan bahwa Pasal 81 UUPPLH lebih tetap disebut sebagai uang paksa dibandingkan sebagai denda administratif, perhatikan contoh uang paksa berikut ini:

"Geachte heer X,

(...)

De door $u$ opgerichte loods is zonder omgevingsvergunning en in afwijking van het bestemmingsplan gebouwd...Gelet op het algemeen belang dat gediend is met handhaving zien wij ons geboondzaakt om daartegen handhavend op te treden. Van bijzondere omstandigheden die het rechtvaardigen om van handhaving af te zien, is naar ons oordeel geen sprake. Gelet op het belang van de openheid van het gebied, zijn wij namelijk niet van plan mee te werken aan de legalisering van de loods. Evenmin is gebleken dat u belang bij voorzetting van de overtreding zwaarder weegt dan de belangen die gediend zijn bij handhaving van de Wabo.

... Leggen wij $u$, de heer X van de Y-straat te Amsterdam, als overtreder, onder oplegging van een dwangsom de last op om de door uw opgerichte loods af te breken, binnen een termijn van 3 maanden na de dag van verzending van deze beschikking... We stellen het bedrag van de dwangsom vast op euro 2100 per week een maximuum te verbeuren dwangsom van euro 6300."

Lihat: M.N. Boeve, et al., op cit., hal. 402-403.

Kutipan di atas memperlihatkan bahwa pemerintah pertama-tama menyatakan bahwa bangunan dari Tuan X telah dibangun tanpa izin lingkungan dan telah melanggar rencana tata ruang. Pemerintah menganggap bahwa demi kepentingan publik, pemerintah harus segera mengambil tindakan terhadap 
administrasi. Hal ini dapat dilihat dari penjelasan berikut.

Ogus dan Abbot mengembangkan model sederhana dari Becker yang memperlihatkan bahwa seorang pelaku tindak pidana akan melakukan perbuatannya jika manfaat (B) dari perbuatan tersebut lebih tinggi dari biaya (C) dari perbuatan tersebut: B > C. Biaya dari sebuah perbuatan pidana terdiri dari sanksi (S) dan probabilitas penjatuhan sanksi (p). Hal ini berarti bahwa: $B>p . S$

Dengan demikian, untuk manfaat tertentu dari sebuah perbuatan, sanksi yang dijatuhkan adalah: ${ }^{113}$

$$
S>B / p
$$

Sementara itu, Abbot mengaitkan pula antara besaran sanksi (S) dengan tingkat bahaya $(\mathrm{H})$ yang dihasilkan oleh sebuah tindak pidana. Menurutnya, sanksi yang dijatuhkan adalah: ${ }^{114}$

$$
S>H / p
$$

Konsep sederhana di atas memperlihatkan bahwa sanksi akan semakin berat seiring dengan meningkatnya keuntungan bagi pelanggar, atau bahaya yang dihasilkan dari pelanggaran. Pada sisi lain, konsep sederhana itu memperlihatkan pula bahwa untuk mengompensasi probabilitas penghukuman yang rendah (kurang dari 100\%), maka sanksi tidak dapat hanya berupa perintah untuk menghentikan pelanggaran dan memperbaiki akibat pelanggaran. Sanksi harus pula bersifat menghukum. Semakin sulit penjatuhan sanksi, semakin tinggi ancaman hukuman yang diberikan.

Meskipun konstruksi Becker terutama berlaku untuk pidana, sanksi yang bersifat menghukum dapat pula dijatuhkan dalam konteks hukum administrasi. Faure dan Svatikova menyatakan bahwa dalam kondisi tertentu, sanksi administratif yang bersifat punitif lebih optimal

\footnotetext{
bangunan tersebut. Pemerintah juga melihat tidak adanya kondisi tertentu yang dapat menunda penegakan hukum. Pemerintah juga menganggap karena pentingnya area tersebut sebagai area terbuka, pemerintah menganggap tidak merasa perlu untuk bekerja sama dengan Tuan $X$. Pemerintah juga menilai bahwa manfaat Tuan $\mathrm{X}$ untuk meneruskan pelanggarannya tidak lebih besar dibandingkan manfaat dari penegakan hukum lingkungan (Wabo). Karena itu, pemerintah memerintahkan Tuan X untuk membongkar bangunannya dalam waktu tiga bulan. Jika perintah ini tidak dilaksanakan, maka pemerintah akan mewajibkan pembayaran sebesar Euro 2100 per minggu, atau paling tinggi sebesar Euro 6300.

${ }^{113}$ Anthony Ogus dan Carolyn Abbot, "Pollution and Penalties", dalam: Timothy Swanson (ed.), An Introduction to the Law and Economics of Environmental Policy: Issues in Institutional Design (London: Elsevier Science Ltd., 2002), hlm. 502.

Gary Becker, peraih Hadiah Nobel bidang ekonomi tahun 1992, mengembangkan model dari pemikiran dasar bahwa pelaku pelanggaran (tindak pidana) merupakan orang yang rasional. Mereka hanya akan melakukan tindak pidananya jika perbuatannya itu menghasilkan manfaat yang lebih besar dibandingkan dengan ongkos yang harus dipikulnya, yaitu sanksi manakala perbuatannya terdeteksi.

${ }^{114}$ Carolyn Abbot, Enforcing Pollution Control Regulation: Strengthening Sanctions and Improving Deterrence (Portland, OR: Hart Publishing, 2009), hal. 24.
} 
dibandingkan dengan sanksi pidana. Hal ini terutama terjadi ketika bahaya yang ditimbulkan kecil sehingga pelanggar akan memiliki aset yang cukup untuk membayar sanksi dan dendanya. Sanksi administratif yang bersifat punitif lebih superior dari pidana karena dapat bersifat mencegah serta memerlukan standar pembuktian yang lebih rendah dan biaya yang lebih murah dibandingkan dengan pidana. ${ }^{115}$

Dari konstruksi Beckerian tersebut, dapat dilihat persoalan hipotetis berikut. Asumsikan bahwa tidak mengoperasikan IPAL mampu menghemat Rp 100 juta per bulan. Asumsikan pula bahwa tingkat pengawasan dan pendeteksian rendah, sehingga hanya setelah waktu setahun perbuatan ilegal itu akan diketahui (setelah menghemat Rp 100 juta x 12 $=\mathrm{Rp} 1,2 \mathrm{M})$. Jika sanksinya adalah paksaan pemerintah berupa pengoperasian IPAL, konstruksi hukum Beckerian tersebut menyarankan kepada semua perusahaan untuk tidak mengoperasikan IPAL, karena bukannya pelanggaran tersebut sulit untuk terdeteksi, tetapi juga bahwa kalau pun pelanggaran terdeteksi sanksinya hanya akan diminta untuk mengoperasikan IPAL tersebut.
Dalam kasus PT. Kaswari Unggul vs. Menteri KLHK, terlihat bahwa sanksi paksaan pemerintah yang dijatuhkan oleh tergugat didasarkan pada pertimbangan bahwa penggugat telah melakukan beberapa pelanggaran. Pertama, lahan di wilayah HGU penggugat mengalami kebakaran. Kedua, penggugat tidak melengkapi sarana dan prasarana penanggulangan kebakaran lahan. Ketiga, penggugat tidak melengkapi TPS Limbah B3 sesuai persyaratan teknis. Keempat, penggugat tidak memiliki izin Penyimpanan Sementara Limbah B3. Kelima, penggugat tidak memelihara kelestarian fungsi lingkungan hidup dan tidak mengendalikan pencemaran dan/ atau kerusakan lingkungan hidup. ${ }^{116}$ Dari uraian tersebut, artikel ini melihat bahwa sebenarnya PT. Kaswari Unggul telah melakukan pelanggaran sangat serius, antara lain, berupa tidak sesuainya TPS limbah B3 dengan syarat teknis dan tidak adanya izin untuk penyimpanan limbah B3.

Dalam kasus tersebut, Pemerintah menjatuhkan sanksi paksaan pemerintah yaitu:

1. Memerintahkan penggugat (PT Kaswari Unggul) untuk mengembalikan lahan eks area ke-

\footnotetext{
${ }^{115}$ Michael G. Faure dan Katarina Svatikova, "Criminal or Administrative Law to Protect the Environment? Evidence fromWestern Europe," Journal of Environmental Law, Vol. 24:2(2012), hal. 258-259.

${ }^{116}$ Indonesia, Pengadilan Tata Usaha Negara, PT. Kaswari Unggul vs. Menteri KLHK, PTUN Jakarta Nomor 104/G/LH/2017/PTUN-JKT (PTUN Jakarta, 2017), hlm. 7-8.
} 
bakaran di area kerjanya kepada Negara sesuai peraturan perundang-undangan, dalam jangka waktu paling lama 60 hari.

2. Memerintahkan Penggugat untuk melengkapi sarana dan prasarana penanggulangan kebakaran hutan dan lahan di Distrik Sungai Beyuku, paling lama 30 hari.

3. Memerintahkan Penggugat untuk melengkapi TPS Limbah B3 sesuai persyaratan teknis, paling lama 30 hari. Keempat, memerintahkan Penggugat untuk memiliki izin Penyimpanan Sementara Limbah B3, paling lama 60 hari.

4. Memerintahkan Penggugat untuk melakukan permintaan maaf kepada publik melalui media masa nasional, paling lama 14 hari. ${ }^{117}$

Sanksi yang dijatuhkan oleh pemerintah tersebut sangat ringan, tidak sebanding dengan pelanggaran, serta sangat mungkin tidak akan menimbulkan efek jera yang memadai. Jika terhadap pelanggaran berupa TPS limbah B3 yang tidak memenuhi syarat dan tanpa izin, sanksinya hanya membuat TPS limbah B3 yang memenuhi syarat dan berizin serta permintaan maaf, maka calon pelanggar tidak akan terdorong untuk menyediakan TPS limbah B3 yang baik dan berizin pada saat mereka memulai usaha/kegiatannya. Jika calon pelanggar adalah pelanggar yang rasional, maka pembangunan TPS limbah B3 yang memenuhi syarat dan berizin tidak akan dilakukan sampai hal tersebut diperintahkan oleh pemerintah berdasarkan paksaan pemerintah. Singkatnya, struktur sanksi semacam ini menjadikan pelanggaran akan menghasilkan manfaat (B) yang lebih tinggi dari biayanya (C).

Hilangnya sanksi administratif yang bersifat menghukum, ditambah dengan sanksi paksaan pemerintah yang hanya merupakan tindakan hukum tanpa adanya tindakan nyata, membuat sanksi administratif kehilangan tajinya. Hal ini tampak pula dari observasi d'Hondt yang menyatakan bahwa di Indonesia terdapat anggapan bahwa sanksi administratif adalah sanksi yang lemah. ${ }^{118}$ Dari uraian tersebut, dapat digambarkan bahwa kekeliruan konseptual ternyata dapat berkontribusi mengurangi manfaat sanksi administratif yang seharusnya menjadi senjata ampuh untuk mencegah pelanggaran.

\section{Catatan Penutup}

Sanksi administratif seharusnya menjadi senjata ampuh, yang diibaratkan sebagai racun yang terletak di ekor.

${ }^{117}$ Ibid., hlm. 8.

${ }^{118}$ Laure d'Hondt, "Indonesia's Environmental Law of 2009 and its Administrative Coercion Provisions: A Conceptual Misunderstanding with Large Practical Implications?", July 3, 2013, tersedia pada: <http://dx.doi.org/10.2139/ssrn.2289123>, hal. 4. 
Artikel ini memperlihatkan bahwa racun ini telah hilang. Pertama, dalam konteks sanksi administratif, pelanggaran hukum lingkungan di Indonesia secara konseptual akan dikenakan sanksi berupa perintah untuk melakukan perbuatan tertentu, tanpa adanya kemungkinan bahwa perintah tersebut akan dipaksakan dengan dilakukan sendiri oleh pemerintah atas biaya dan risiko dari pelanggar/penerima sanksi. Kedua, pelanggaran hukum lingkungan juga tidak akan dikenakan sanksi administratif yang bersifat menghukum, yaitu denda.

Kedua persoalan dalam memahami sanksi administratif ini sangat mungkin akan berujung pada melemahnya sanksi administratif sebagai sanksi yang seharusnya paling utama dan pertama dalam pencegahan pelanggaran hukum lingkungan. 


\section{Daftar Pustaka}

\section{Peraturan Perundang-Undangan}

Indonesia, Undang-Undang Perlindungan dan Pengelolaan Lingkungan Hidup,

UU No. 32 Tahun 2009, LN Tahun 2009 No. 140, TLN No. 5059.

Menteri Lingkungan Hidup dan Kehutanan, Peraturan Menteri LH Nomor 2 tahun 2013 tentang Pedoman Penerapan Sanksi Administratif di Bidang Perlindungan dan Pengelolaan Lingkungan Hidup, BN Tahun 2013 Nomor 314.

\section{Putusan pengadilan}

Pengadilan Tata Usaha Negara Jakarta, Putusan Nomor 104/G/LH/2017/ PTUN-JKT

\section{Buku}

Abbot, Carolyn. Enforcing Pollution Control Regulation: Strengthening Sanctions and Improving Deterrence. Portland, OR: Hart Publishing, 2009.

Atmosudirjo, S. Prajudi. Hukum Administrasi Negara, Cet. 10. Jakarta: Ghalia Indonesia, 1994.

Boeve, M.N., et al., Omgevingsrecht, cet. 6 . Amsterdam: Europa Law Publishing, 2019.

Broring, H.E. dan B.F. Keulen. Bestraffende Sancties in het Strafrecht en het Bestuursrecht. Zutphen: Uitgeverij Paris, 2017.

Hadjon, Philipus M., et al. Pengantar Hukum Administrasi Indonesia (Introduction to the Indonesian Administrative
Law), cet. 10. Yogyakarta: Gadjah Mada University Press, 2008.

Heldeweg, Michiel A. dan René J.H.G. Seerden. Environmental Law in the Netherlands. Alphen aan den Rijn: Wolters Kluwer, 2012.

H.R., Ridwan. Hukum Administrasi Nega$r a$, Cet. 3. Jakarta: RajaGrafindo Persada, 2006.

Neerhof, A.R. "Herstelsancties", dalam: L.J.A. Damen, et al. (eds.), Bestuursrecht Deel 1: Systeem, Bevoegdheid, Bevoegdheidsuitoefening, Handhaving, 2de druk. Den Haag: Boom Juridische uitgevers, 2005a.

Neerhof, A.R. "Bestraffende Sancties", dalam: L.J.A. Damen, et al. (eds.), Bestuursrecht Deel I: Systeem, Bevoegdheid, Bevoegdheidsuitoefening, Handhaving, 2de druk. Den Haag: Boom Juridische uitgevers, 2005b.

Ogus, Anthony dan Carolyn Abbot. "Pollution and Penalties", dalam: Timothy Swanson (ed.), An Introduction to the Law and Economics of Environmental Policy: Issues in Institutional Design. London: Elsevier Science Ltd., 2002.

van den Brekel, P.M., E.M.J. Hardy, dan N.J.A.P.B. Niessen. Bestuursrecht. Den Haag: Boom Juridische uitgevers, 2007.

van Wijk, H.D., Willem Konijnenbelt, dan Ron van Male. Hoofdstukken van Bestuursrecht. Den Haag: Elsevier Juridisch, 2008. 


\section{Artikel Jurnal/Media Massa}

Anonymous. "Sanction and Procedures Applicable to Breaches of the Legislation on Industrial Emissions in the Netherlands," Eastern and Central European Journal on Environmental Law, Vol. 16:1 (2012).

de Moor-van Vugt, Adrienne. "Administrative Sanctions in EU Law," Review of European Administrative Law, Vol. 5:1 (Spring 2012).

d'Hondt, Laure. "Indonesia's Environmental Law of 2009 and its Administrative Coercion Provisions: A Conceptual Misunderstanding with Large Practical Implications?", July 3, 2013, tersedia pada: <http://dx. doi.org/10.2139/ssrn.2289123>.

Faure, Michael. "Effectiveness of Environmental Law: What Does the Evidence Tell Us," William \& Mary Environmental Law and Policy Review, Vol. 36:2 (Winter 2012).

Faure, Michael G. dan Katarina Svatikova. "Criminal or Administrative Law to Protect the Environment? Evidence from Western Europe," Journal of Environmental Law, Vol. 24:2(2012).

Macrory, Richard. "Environmental Sanctions," Environmental Policy and Law, Vol. 45:6 (November, 2015).

\section{Lain-Lain}

Ditjen GAKKUM KLHK.“Tiga Tahun Direktorat Jenderal Penegakan $\mathrm{Hu}$ kum Lingkungan Hidup dan Kehutanan 2015-2017", tersedia pada:

https://docplayer.info/71504638-
Tiga-tahun-direktorat-jenderal-penegakan-hukum-lingkungan-hidupdan-kehutanan.html

Ditjen GAKKUM KLHK. "Capaian Penegakan Hukum Lingkungan Hidup dan Kehutanan 2016", tersedia pada: https:// docplayer.info/71110632Capaian-penegakan-hukum-lingkungan-hidup-dan-kehutanan-januari-direktorat-jenderal-penegakanhukum.html 